Research Paper

\title{
Photodynamic Treatment of Oral Squamous Cell Carcinoma Cells with Low Curcumin Concentrations
}

\author{
Kim Beyer1, 2, Frangis Nikfarjam¹,2, Manuel Butting1, Markus Meissner¹, Anke König1, Ana Ramirez Bosca ${ }^{3}$, \\ Roland Kaufmann"1, Detlef Heidemann², August Bernd ${ }^{1}$, Stefan Kippenberger ${ }^{1}$, Nadja Zöller ${ }^{1 凶}$ \\ 1. J.W. Goethe-University, Medical School, Department of Dermatology, Venereology and Allergology, Theodor-Stern-Kai 7, 60590 Frankfurt/Main, Germany; \\ 2. Department of Operative Dentistry, Center for Dentistry and Oral Medicine (Carolinum), J.W. Goethe-University Frankfurt, Theodor-Stern-Kai 7, 60590 \\ Frankfurt/Main, Germany. \\ 3. Servico De Dermatologia. Hospital Vinalopo, Tónico Sansano Mora 14, 03293 Elche, Spain. \\ $\square$ Corresponding author: Nadja Nicole Zöller Phone: +49 (0) 6963015585 Fax: +49 (0) 6963016466 e-mail: Nadja.Zoeller@kgu.de \\ (C) Ivyspring International Publisher. This is an open access article distributed under the terms of the Creative Commons Attribution (CC BY-NC) license \\ (https://creativecommons.org/licenses/by-nc/4.0/). See http://ivyspring.com/terms for full terms and conditions.
}

Received: 2016.08.12; Accepted: 2017.03.31; Published: 2017.05.11

\begin{abstract}
Objective: Curcumin is known for its anti-oxidative, anti-inflammatory and anti-tumorigenic qualities at concentrations ranging from $3.7 \mu \mathrm{g} / \mathrm{ml}$ to $55 \mu \mathrm{g} / \mathrm{ml}$. Therefore it is pre-destined for tumour therapy. Due to high oral doses that have to be administered and the low bioavailability of curcumin new therapy concepts have to be developed. One of these therapy concepts is the combination of low curcumin concentrations and UVA or visible light. Aim of our study was to investigate the influence of this treatment regime on oral squamous cell carcinoma cells.

Materials and Methods: A human oral squamous cell carcinoma cell line $(H N)$ was pre-incubated with low curcumin concentrations $(0.01 \mu \mathrm{g} / \mathrm{ml}$ to $1 \mu \mathrm{g} / \mathrm{ml})$. Thereafter cell cultures were either left un-irradiated or were irradiated either with $1 \mathrm{~J} / \mathrm{cm}^{2}$ UVA or for $5 \mathrm{~min}$ with visible light. Quantitative analysis of proliferation, membrane integrity, oxidative potential and DNA fragmentation were done.

Results: It could be shown that low curcumin concentrations neither influenced proliferation, nor cell morphology, nor cell integrity nor apoptosis. When combining these curcumin concentrations with UVA or visible light irradiation cell proliferation as well as development of reactive oxygen species was reduced whereas DNA fragmentation was increased. Concentration as well as light entity specific effects could be observed.

Conclusions: The present findings substantiate the potential of the combination of low curcumin concentrations and light as a new therapeutic concept to increase the efficacy of curcumin in the treatment of cancer of the oral mucosa.
\end{abstract}

Key words: head and neck cancer, curcumin, apoptosis, proliferation, UVA, VIS.

\section{Introduction}

Oral squamous cell carcinomas are among the widest spread malign tumours [1]. Late diagnosis due to the asymptomatic, fast and aggressive progression $[2,3]$ and early occurring metastasis of the tumour are responsible for a 5 year survival rate of $39-43 \%[4,5]$. Local excision, chemotherapy, radiotherapy and combinations thereof are common treatment regimens [6-9]. To increase the survival rate new treatment regimens and drugs are required.
Natural compounds play a significant role in drug discovery and development [10, 11]. One of these natural compounds with broad spectrum of physiological effects is curcumin. The phytochemical can be isolated from the rhizome of the ginger plant Curcuma longa. For thousands of years it has been a part of the traditional Asian medicine. Among others it is known for its anti-inflammatory and antioxidative potential [12]. Taking into account the 
hardly existing toxicity, curcumin is a promising substance to develop anti-tumorigenic therapeutic strategies. Obstacles are the low bioavailability of curcumin due to low resorption from the gastrointestinal tract, low solubility [13] and fast metabolisation [14]. Therefore even after administering high curcumin concentrations pharmacological relevant effects are not achievable $[15,16]$. Inhibiting metabolic degradation [17, 18], encapsulating curcumin in micelles [19] or binding to nanoparticles [20-22] are strategies to increase the curcumin concentration in the serum. Another possible therapy concept is the combination of low concentrations of curcumin $(0.1-2 \mu \mathrm{g} / \mathrm{ml})$ with UVA or visible light (VIS) [23-25]. Aim of this study was to investigate the influence of curcumin in combination with light on oral squamous cell carcinoma cells.

\section{Materials and Methods}

\section{Cell culture and treatment}

The human oral squamous cell carcinoma cell line (HN ACC 417, DSMZ, Leipzig, Germany), the spontaneous immortalized human keratinocyte cell line HaCaT [26] and the human epidermoid carcinoma cell line A431 (ATCC ${ }^{\circledR}$ CRL1555 ${ }^{\mathrm{TM}}$ ) were cultured in Dulbecco's Modified Eagle's Medium (D-MEM, Gibco, Karlsruhe, Germany) with GlutaMax supplemented with $10 \%(\mathrm{v} / \mathrm{v})$ fetal calf serum (FCS, PAA, Cölbe, Germany) and $1 \%$ (v/v) penicillin/streptomycin solution (Gibco) in $7.5 \% \mathrm{CO}_{2}$ atmosphere at $37^{\circ} \mathrm{C}$. Curcumin (Sigma-Aldrich Taufkirchen, Germany) was dissolved as previously described [23, 27]. Briefly, cells were incubated for $1 \mathrm{~h}$ with medium containing $0.01 \mu \mathrm{g} / \mathrm{ml}$ to $1 \mu \mathrm{g} / \mathrm{ml}$ curcumin. For irradiation either with $1 \mathrm{~J} / \mathrm{cm}^{2}$ ultraviolet A (UVA, Waldmann, VillingenSchwenningen, Germany) or visible light (VIS, 5500 lx, Philips GmbH, Hamburg, Germany) the medium was replaced with PBS (Gibco) or PBS curcumin. After irradiation PBS was replaced with culture medium containing no curcumin.

\section{Morphological properties}

$\mathrm{HN}$ cells were cultivated in microwell plates at a density of $1 \times 10^{4}$ cells $/ 0.33 \mathrm{~cm}^{2}$ and were exposed to curcumin as mentioned. Immediately after irradiation cells were transferred to the incubator microscope unit. Morphological properties were monitored, analysed and photodocumented every $2 \mathrm{~h}$ for $16 \mathrm{~h}$ with the incubator microscope unit IncuCyte (EssenBioScience, Hertfordshire, UK).

\section{Cell proliferation}

Cells were cultivated in microwell plates at a density of $2 \times 10^{4}$ cells $/ 0.33 \mathrm{~cm}^{2}$. Cells were exposed to curcumin as mentioned. Immediately after irradiation cells were pulsed for $16 \mathrm{~h}$ with 5-bromo-2'deoxyuridine (BrdU). The incorporation rate of BrdU was determined using a commercial enzyme-linked immunosorbent assay (ELISA) kit (Roche, Mannheim, Germany) as previously described [28]. Briefly, cells were fixed and immune complexes were formed using peroxidase-coupled BrdU-antibodies. A colorimetric reaction with tetramethylbenzidine as a substrate gave rise to a reaction product measured at $450 \mathrm{~nm}$ in a scanning multiwell spectrophotometer (ELISA reader, MR 5000; Dynatech, Guernsey, UK).

\section{Membrane integrity}

Cell lysis was quantified using the cytotoxicity detection kit (Roche), which is based on the release of lactate dehydrogenase (LDH) from damaged cells. Briefly, HN cells were seeded in microwell plates as described above and were treated with curcumin and UVA or VIS. As a positive control (maximal cell damage), cells were treated with $1 \%$ Triton X-100 (Merck, Darmstadt, Germany). Subsequently, the cell-free supernatants were incubated with $\mathrm{NAD}^{+}$, which is reduced by $\mathrm{LDH}$ to $\mathrm{NADH} / \mathrm{H}^{+}$. In a second step, $\mathrm{NADH} / \mathrm{H}^{+}$reduces a yellow tetrazolium salt to a red-coloured formazan salt. The amount of red colour is proportional to the number of lysed cells. For quantitation, the absorbance of the reaction product was measured at $490 \mathrm{~nm}$ using a multiwell spectrophotometer.

\section{Reactive oxygen species generation}

Oxidation of dihydrorhodamine 123, an oxidation-sensitive indicator, which can be converted to the fluorescent derivative rhodamine 123 , namely by superoxide and hydrogen peroxide $[29,30]$ was used as indicator for free radical generation as previously described [24]. HN cells were pre-incubated with the respective curcumin media and $10 \mathrm{mM}$ dihydrorhodamine 123 for $1 \mathrm{~h}$. Thereafter the cells were washed with PBS and irradiated for 5 min with VIS. Rhodamine 123 fluorescence was consecutively measured every 10min (excitation $485 \mathrm{~nm}$, emission at 530nm) using a CytoFluor (series 4000, PerSeptive Biosystems, Framingham, USA).

\section{Apoptosis}

DNA fragmentation was chosen as indicator of apoptosis. Quantification was performed with the Cell Death Detection ELISA (CDD; Roche, Mannheim, Germany) according to the manufacturer's specifications. Cells were seeded in 96-well microtiter plates with a density of approximately $2 \times 10^{4}$ cells $/ 0.33 \mathrm{~cm}^{2}$. On the following day cells were treated as described above. $15 \mathrm{~h}$ after the treatment 
culture medium was discarded and the adherent cells were lysed and further processed as described [23].

\section{Immunhistochemical analysis of cleaved caspase-3}

$\mathrm{HN}$ cells were seeded in a cell density of $2 \times 10^{4}$ cells $/ \mathrm{ml}$ on glass cover slides. On the following day the cultures were treated as described above or treated with $1 \mu \mathrm{M}$ or $10 \mu \mathrm{M}$ camptothecin (Sigma-Aldrich) as positive control. All cultures were fixed after $4 \mathrm{~h}$ in $4 \%$ paraformaldehyd (Carl Roth) for $15 \mathrm{~min}$ at room temperature. Thereafter the cultures were washed three times for 10min with PBS before blocking with PBS containing 5\% (v/v) bovine serum albumin (Carl Roth) and $0.3 \%$ Triton X-100 for $60 \mathrm{~min}$. Subsequently cells were stained overnight at $4^{\circ} \mathrm{C}$ with 1:500 diluted polyclonal rabbit anti-human cleaved caspase-3 (ASP-175, Cell Signaling, Frankfurt, Germany). Before incubating with 1:500 diluted polyclonal goat anti-rabbit IgG $(\mathrm{H}+\mathrm{L})$, Alexa Fluor 546 conjugated (Thermo Fisher Scientific, Rockford, USA) for $2 \mathrm{~h}$ at room temperature, cells were washed three times with PBS. After the secondary antibody incubation cells were washed again three times for $10 \mathrm{~min}$ in PBS. Cell nuclei were counterstained with DAPI (Thermo Fisher Scientific) for $10 \mathrm{~min}$ at room temperature and washed briefly in PBS and demineralised water. Coverslips were covered with Aqua Poly Mount (Polysciences, Hirschberg an der Bergstrasse, Germany) and fixed on microscope slides. Photographs were taken with a digital camera (Sony Cyber Shot 3.3, Sony, Cologne, Germany) connected to an Olympus BX-50 (Olympus, Hamburg, Germany) and processed with ImageJ [31].

\section{Presentation of data and statistical analysis}

All data are presented as mean values \pm standard deviation. Statistical significance of the data was evaluated by the Wilcoxon-Mann-Whitney U-test (BIAS, Frankfurt, Germany). Each set of data was related to the referring untreated control. Differences were considered significant at $\mathrm{p} \leq 0.05:{ }^{*}, \mathrm{p} \leq 0.01$ : **, \#\#, $\mathrm{p} \leq 0.001:^{* * *}$, \#\#\#.

\section{Results}

\section{Influence of curcumin on cell morphology}

First of all we investigated whether cell morphology was influenced by curcumin and/or the applied combination treatment. $\mathrm{HN}$ cells were pre-incubated with curcumin $(0.01 \mu \mathrm{g} / \mathrm{ml}-1 \mu \mathrm{g} / \mathrm{ml})$. Subsequently, they were either left un-irradiated, were irradiated with $1 \mathrm{~J} / \mathrm{cm}^{2}$ UVA or were irradiated for $5 \mathrm{~min}$ with VIS. Immediately after the treatment the cultures were monitored every second hour for $16 \mathrm{~h}$ with an incubator microscope unit. Cell morphology did not alter in cultures treated solely by the specified curcumin concentrations. In cultures treated with curcumin concentrations of $0.8 \mu \mathrm{g} / \mathrm{ml}$ and $1 \mu \mathrm{g} / \mathrm{ml}$ in combination with UVA (Fig. 1) as well as in cultures treated with $0.6 \mu \mathrm{g} / \mathrm{ml}$ and $0.8 \mu \mathrm{g} / \mathrm{ml}$ curcumin in combination with VIS (Fig. 2) cell retraction and dynamic plasma membrane blebbing were evident. Clear discrimination between mitotic and apoptotic cells was possible (Fig. 3).

\section{Influence of curcumin on membrane integrity}

After showing irradiation and curcumin concentration dependent morphological changes of HN cells we ascertained whether cell integrity was influenced by curcumin and/or the applied combination treatment. HN cells were pre-incubated and irradiated as described before. After $24 \mathrm{~h}$ the enzyme activity of lactate dehydrogenase in cell free supernatants was analysed. Curcumin without light treatment had no effect on lactate dehydrogenase liberalisation (Fig. 4, white bars). After irradiation with either UVA (Fig. 4A, striped bars) or VIS (Fig. 4B, black bars) we observed that the enzyme activity increased depending on the applied curcumin concentrations. Lactate dehydrogenase activity in supernatants increased after UVA irradiation when applying $0.4 \mu \mathrm{g} / \mathrm{ml}-1 \mu \mathrm{g} / \mathrm{ml}$ curcumin. After VIS irradiation significant lactate dehydrogenase enzyme activity increase was observed for curcumin concentration of $0.05 \mu \mathrm{g} / \mathrm{ml}$. Maximal activity increase was reached when applying $0.4 \mu \mathrm{g} / \mathrm{ml}$ curcumin after VIS irradiation. After irradiation with UVA a steady increase was observed for the tested curcumin concentrations. As positive control $\mathrm{HN}$ cells were treated with $1 \%$ Triton X-100 (bricked bars). Comparison of these cultures to the controls or to the curcumin treated cultures revealed a highly significant activity increase caused by Triton X-100. 


\begin{tabular}{|c|c|c|c|}
\hline Curcumin $[\mu \mathrm{g} / \mathrm{ml}]$ & $\begin{array}{c}\text { unirradiated } \\
0 \mathrm{~h}\end{array}$ & $\begin{array}{c}\text { unirradiated } \\
16 \mathrm{~h}\end{array}$ & $16 \mathrm{~h}$ \\
\hline control & $\mathrm{A}$ & $\mathrm{B}$ & $\mathrm{C}$ \\
\hline 0.6 & $\mathrm{D}$ & $\mathrm{E}$ & $\mathrm{F}$ \\
\hline 0.8 & $\mathrm{G}$ & $\mathrm{H}$ & $\mathrm{I}$ \\
\hline 1.0 & $\mathrm{~J}$ & $\mathrm{~K}$ & $\mathrm{~L}$ \\
\hline
\end{tabular}
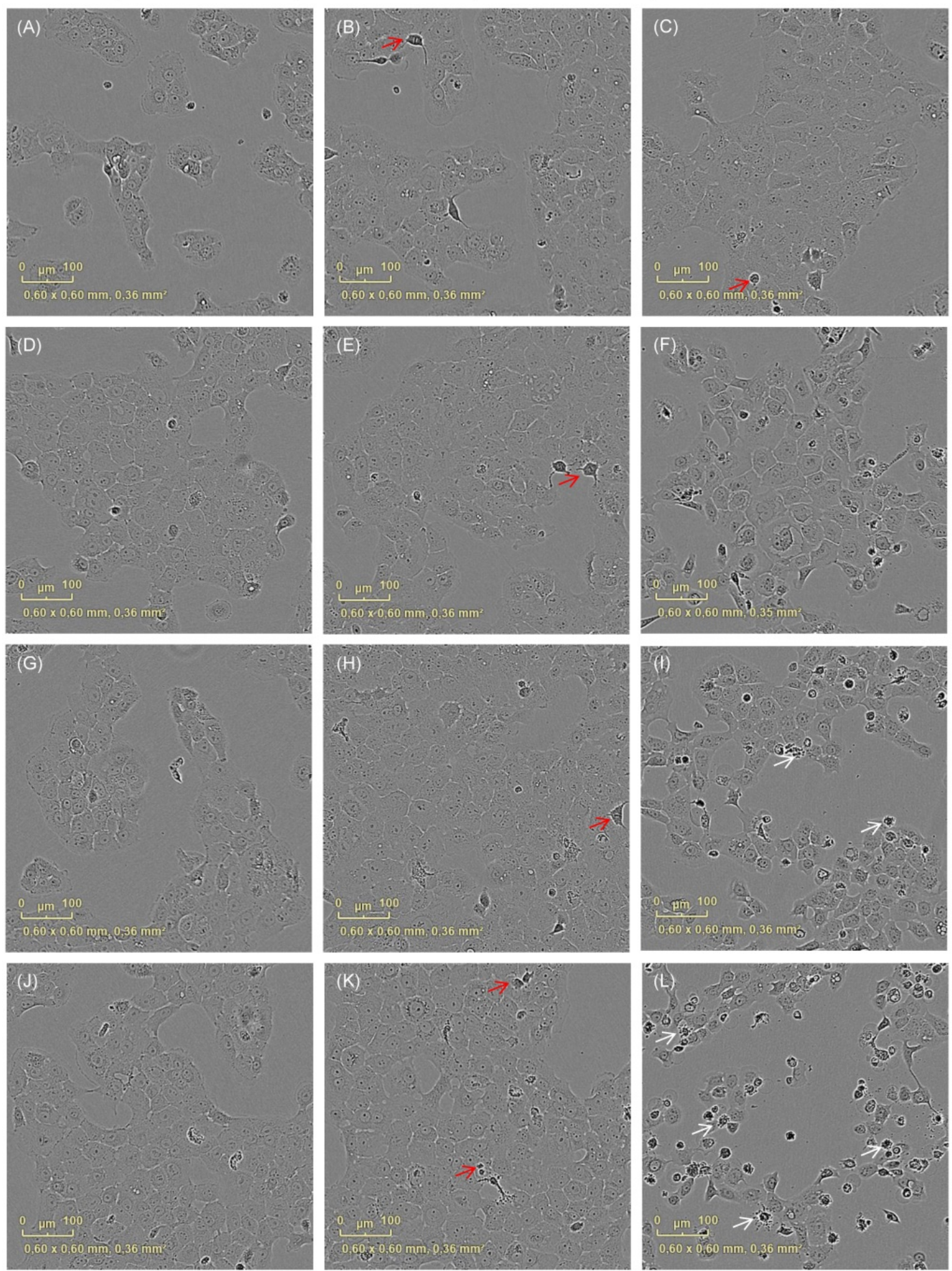

Figure 1. Cell morphology after irradiation with UVA changes depending on the curcumin concentrations. Cell integrity was monitored with an incubator microscope unit immediately after the treatment and after $16 \mathrm{~h}$. Morphological criteria of mitotic cells (red arrows) as well as apoptotic cells (white arrows) were observable and exemplarily marked. 


\begin{tabular}{|c|c|c|c|}
\hline Curcumin $[\mu \mathrm{g} / \mathrm{ml}]$ & $\begin{array}{c}\text { unirradiated } \\
0 \mathrm{~h}\end{array}$ & $\begin{array}{c}\text { unirradiated } \\
16 \mathrm{~h}\end{array}$ & $16 \mathrm{~h}$ \\
\hline control & $\mathrm{A}$ & $\mathrm{B}$ & $\mathrm{C}$ \\
\hline 0.4 & $\mathrm{D}$ & $\mathrm{E}$ & $\mathrm{F}$ \\
\hline 0.6 & $\mathrm{G}$ & $\mathrm{H}$ & $\mathrm{I}$ \\
\hline 0.8 & $\mathrm{~J}$ & $\mathrm{~K}$ & $\mathrm{~L}$ \\
\hline
\end{tabular}
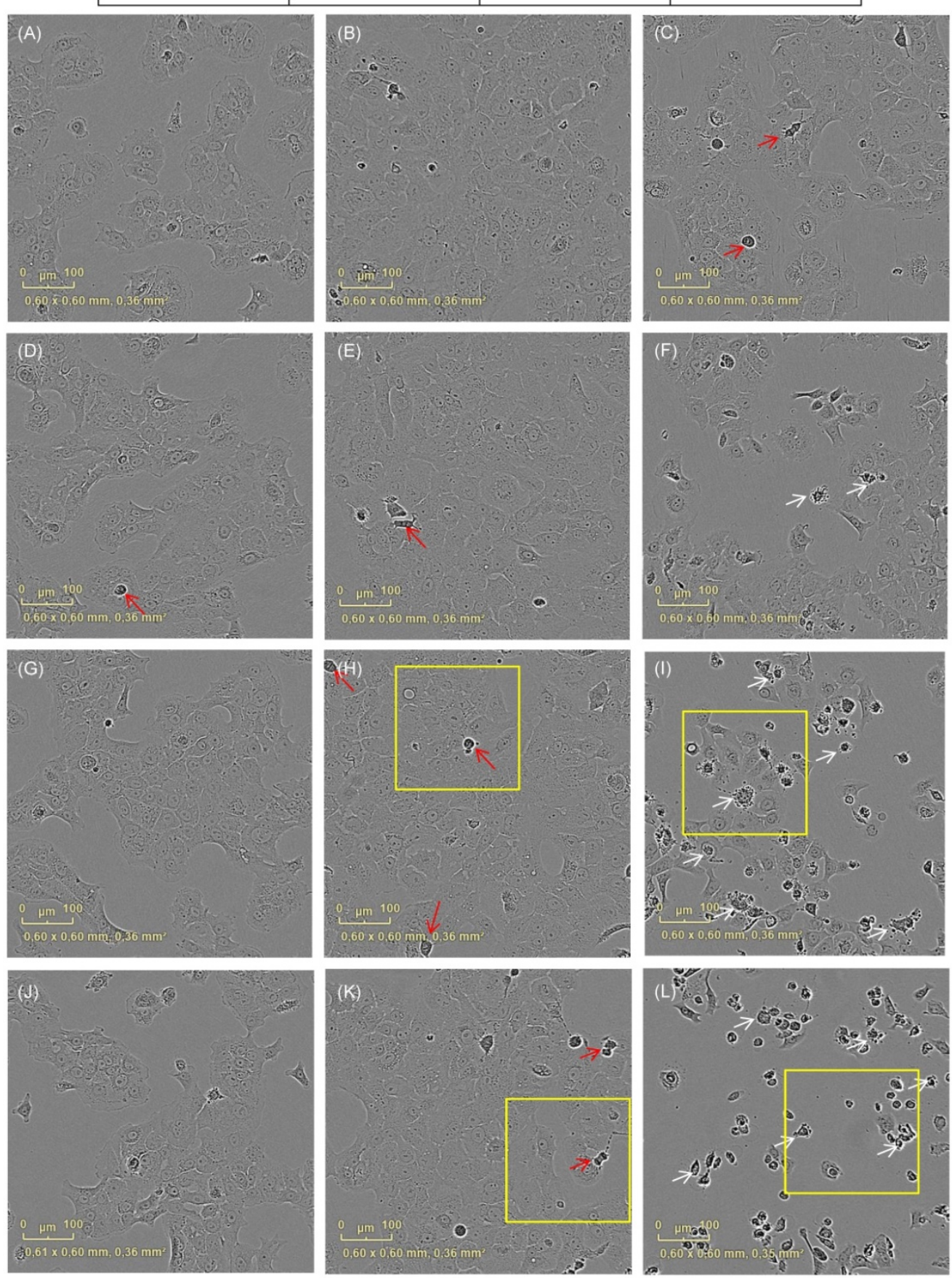

Figure 2. Cell morphology changes after irradiation with VIS depending on the applied curcumin concentrations. Cell integrity was monitored with an incubator microscope unit immediately after the treatment and after 16h. Morphological criteria of apoptotic cells (white arrows) were observable after co-treatment with $0.4 \mu \mathrm{g} / \mathrm{ml}(\mathrm{F}), 0.6 \mu \mathrm{g} / \mathrm{ml}(\mathrm{I})$ and $0.8 \mu \mathrm{g} / \mathrm{ml}(\mathrm{L})$ curcumin $16 \mathrm{~h}$ after VIS irradiation in contrast to criteria of mitotic cell (red arrows) that were less observable in the co-treated cultures. Characteristic culture areas (yellow squares) are enlarged in Fig. 3. 

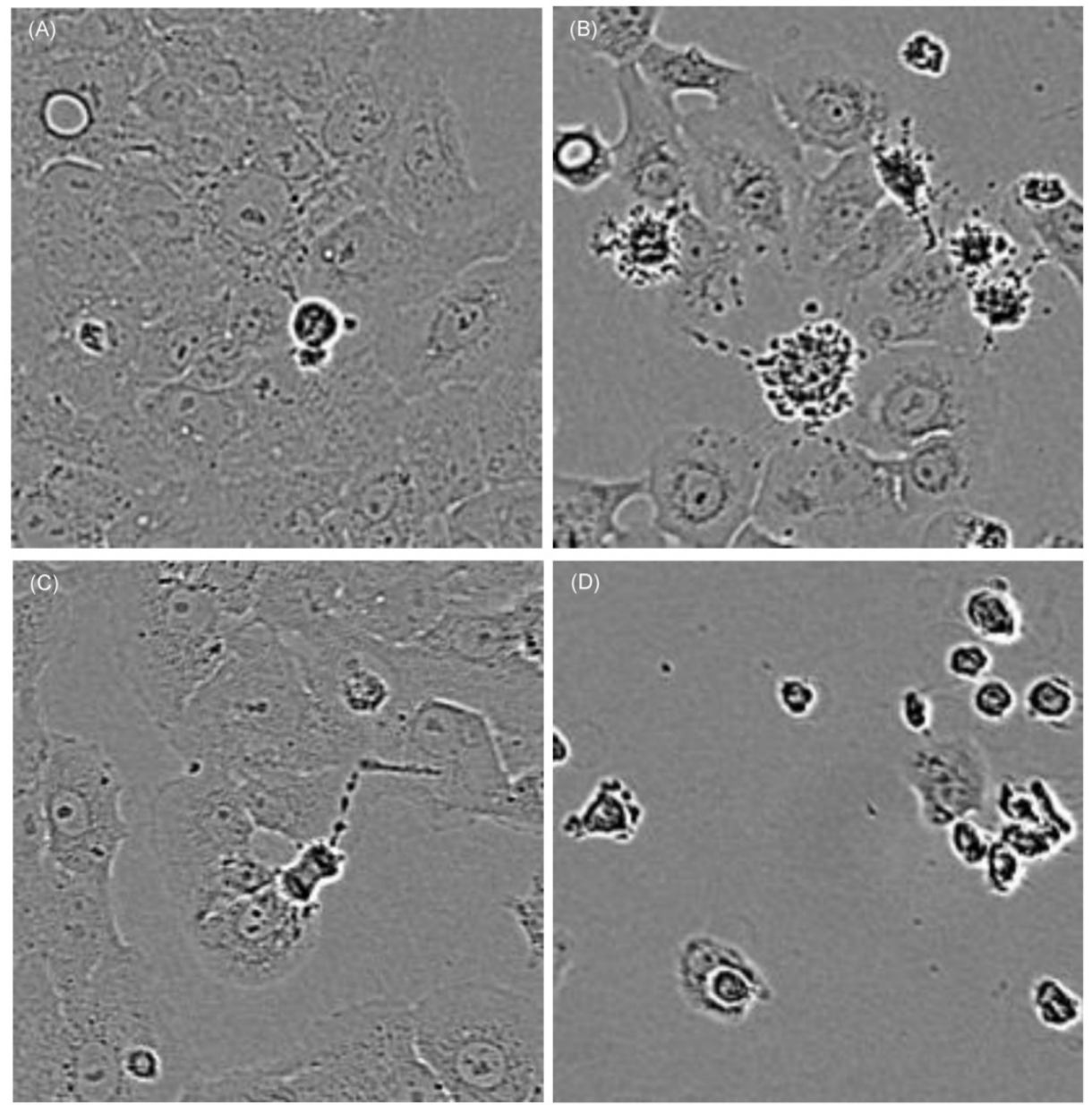

Figure 3. Cells treated with curcumin show mitotic as well as apoptotic morphological criteria depending on the applied curcumin concentration and co-treatment with light. Characteristic cell areas marked by yellow squares in Fig. 2 are herein shown in a higher magnification. Cells were treated for $1 \mathrm{~h}$ with $0.6 \mu \mathrm{g} / \mathrm{ml}(\mathrm{A}, \mathrm{B})$ or $0.8 \mu \mathrm{g} / \mathrm{ml}(\mathrm{C}, \mathrm{D})$ curcumin. Cells that were kept light protected $(\mathrm{A}, \mathrm{C})$ showed clear mitotic activity after $16 \mathrm{~h}$ whereas cells irradiated with VIS (B, D) showed membrane blebbing and complete cell retraction.

\section{DNA synthesis was impaired after curcumin and light treatment}

HN cells were pre-exposed to curcumin before irradiation. The impact on proliferation was analysed by monitoring the incorporation of $\mathrm{BrdU}$ as thymidine base analogue during the S-phase of mitosis. Curcumin alone or irradiation alone did not influence BrdU incorporation in any way (Fig. 5 white bars). Analysis after UVA (Fig. 5A, striped bars) or VIS (Fig. 5B, black bars) irradiation showed that the amount of incorporated BrdU and therefore the proliferation potential was significantly reduced in the samples that had been exposed to curcumin. Administering $0.8 \mu \mathrm{g} / \mathrm{ml}$ curcumin before UVA treatment reduced BrdU incorporation to $71 \%$ of the irradiated control. The same curcumin concentration and VIS irradiation reduced the BrdU incorporation to $37 \%$ of the respective irradiated control. Even low concentrations of $0.05 \mu \mathrm{g} / \mathrm{ml}$ after VIS irradiation revealed a $17 \%$ lower BrdU incorporation rate than in irradiated control cultures. To classify whether $\mathrm{HN}$ cells are more sensitive to the described photodynamic treatment than other cells direct comparison to the spontaneously immortalized keratinocyte cell line $\mathrm{HaCaT}$ and the epidermoid cancer cell line A431 was performed (Fig. 6). In all three cell lines curcumin concentration dependent BrdU incorporation reduction after VIS irradiation was evident. Furthermore it could be shown that a highly significant lower BrdU incorporation after treatment with $0.6 \mu \mathrm{g} / \mathrm{ml}$ and $0.8 \mu \mathrm{g} / \mathrm{ml}$ curcumin in combination with VIS could be observed in HN (black bars) cells than in A431 (bricked bars) or HaCaT (pointed bars) cultures.

\section{The concentration of VIS induced reactive oxygen species was reduced by curcumin}

Generation of reactive oxygen species (ROS) is a known parameter for evaluation of the phototoxic potential of photosensitizing compounds [32-34]. Monitoring the generation of ROS after curcumin and light treatment was chosen to study whether curcumin utilizes a similar mode of action. No 
significant induction of ROS was detected by treatment with curcumin alone (Fig. 7, white bars). To induce ROS, cell cultures were irradiated with VIS for $5 \mathrm{~min}$ (Fig. 7, black bars) achieving a 130\% higher ROS level than under control conditions. Analysis of cultures that had been pre-incubated with curcumin before VIS irradiation showed a significant reduction of ROS generation. Pre-incubation with curcumin concentrations of $0.1 \mu \mathrm{g} / \mathrm{ml}$ to $1 \mu \mathrm{g} / \mathrm{ml}$ completely reversed the ROS inducing influence of VIS irradiation. Likewise ROS savaging effects were observed when using $50 \mathrm{mM} \mathrm{H}_{2} \mathrm{O}_{2}$ as ROS inducer (data not shown).
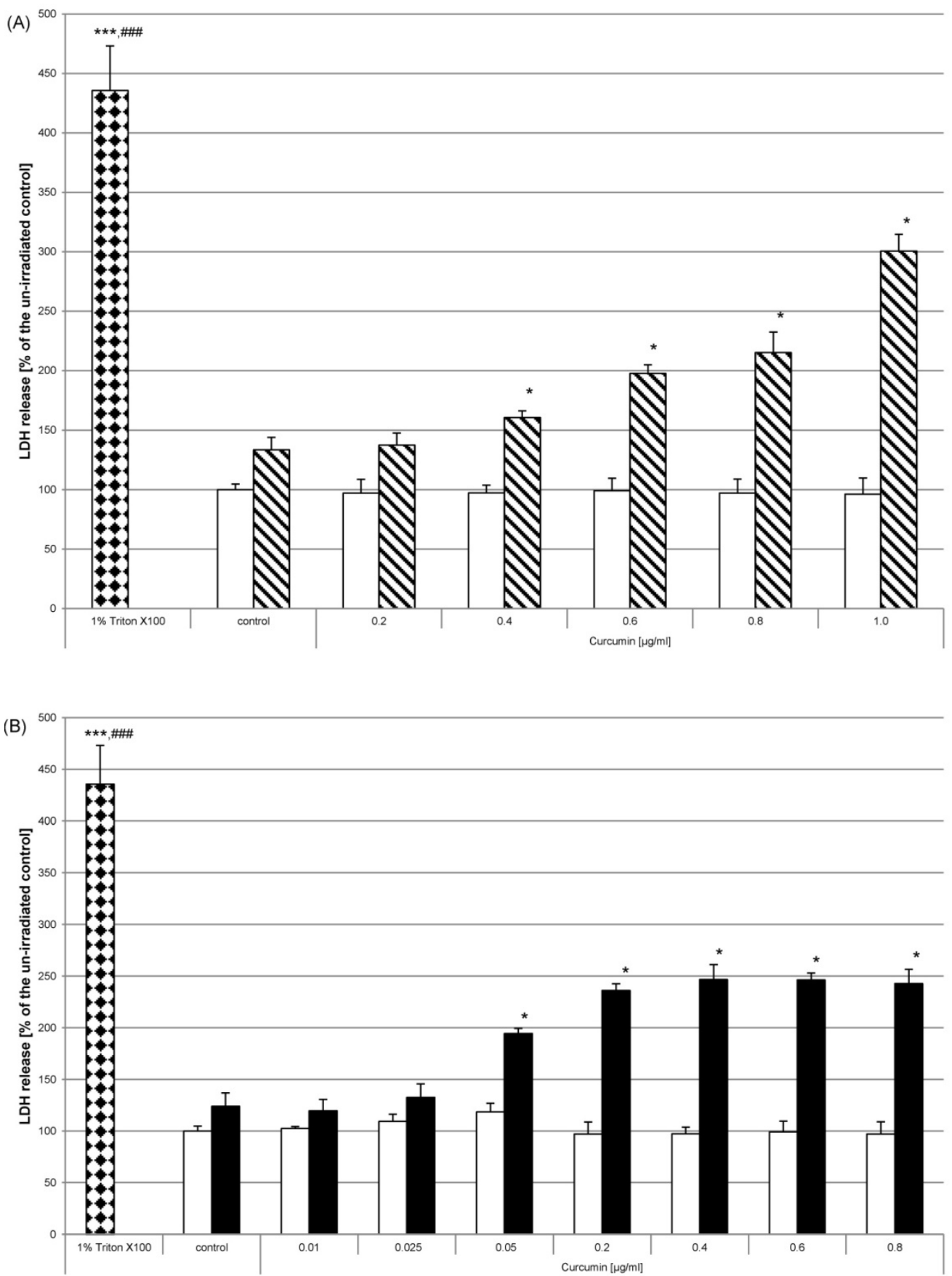

Figure 4. Curcumin influences membrane integrity after irradiation with UVA or VIS. Cell integrity was monitored by assaying LDH activity in supernatants $24 \mathrm{~h}$ after treating HN cells with curcumin and successive UVA (A) or VIS (B) irradiation. Neither the applied curcumin concentrations (white bars) nor one of the light entities alone influenced the membrane integrity of $\mathrm{HN}$ cells. Co-stimulation with curcumin and either of the light sources increased the LDH activity (striped bars, black bars). The positive controls 1\% Triton-X100 (bricked bars) caused maximal LDH activity. The data displayed are representative of three experiments performed with comparable results. Average absorbance values (mean $\pm \mathrm{SD}$ ) from sextuplicate replicates per experimental condition were calculated. $* \mathrm{p} \leq 0.05 ; * * * \mathrm{p} \leq 0.001$ versus the un-irradiated control; \#\# $\mathrm{p} \leq 0.001$ versus any sample. 

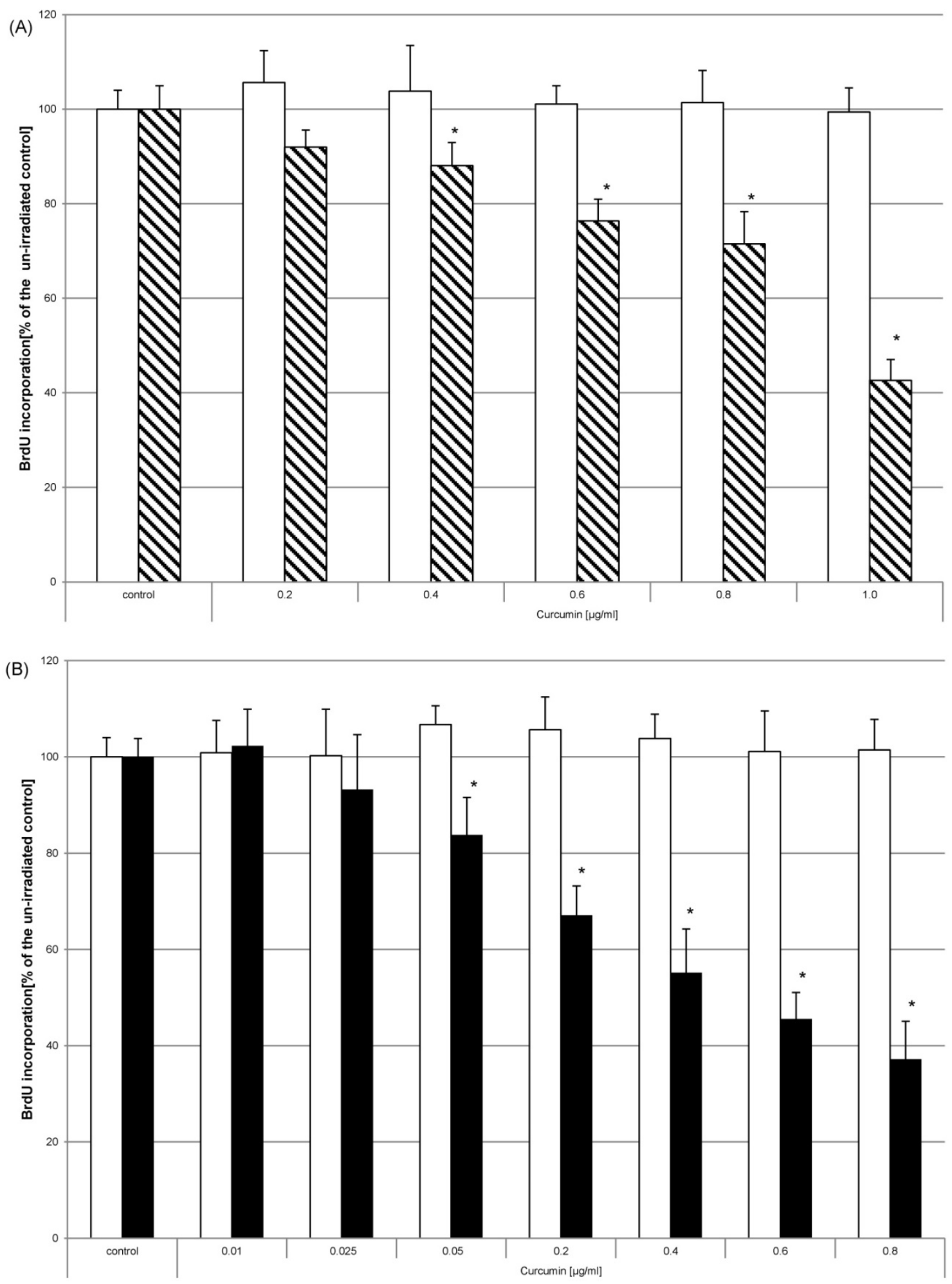

Figure 5. Curcumin in combination with UVA or VIS inhibits proliferation. HN cells were pre-incubated with curcumin and thereafter irradiated with UVA (A) or VIS (B). The proliferative potential was monitored by BrdU incorporation for $16 \mathrm{~h}$ after the treatment. BrdU incorporation was not influenced by administering curcumin in the used concentrations (white bars). Combining these concentrations with either UVA (striped bars) or VIS (black bars) significantly reduced the $\mathrm{BrdU}$ concentration. The data displayed are representative of three experiments performed with comparable results. Average absorbance values (mean $\pm S D$ ) from sextuplicate replicates per experimental condition were calculated. $* p \leq 0.05$ versus the respective un-irradiated control. 


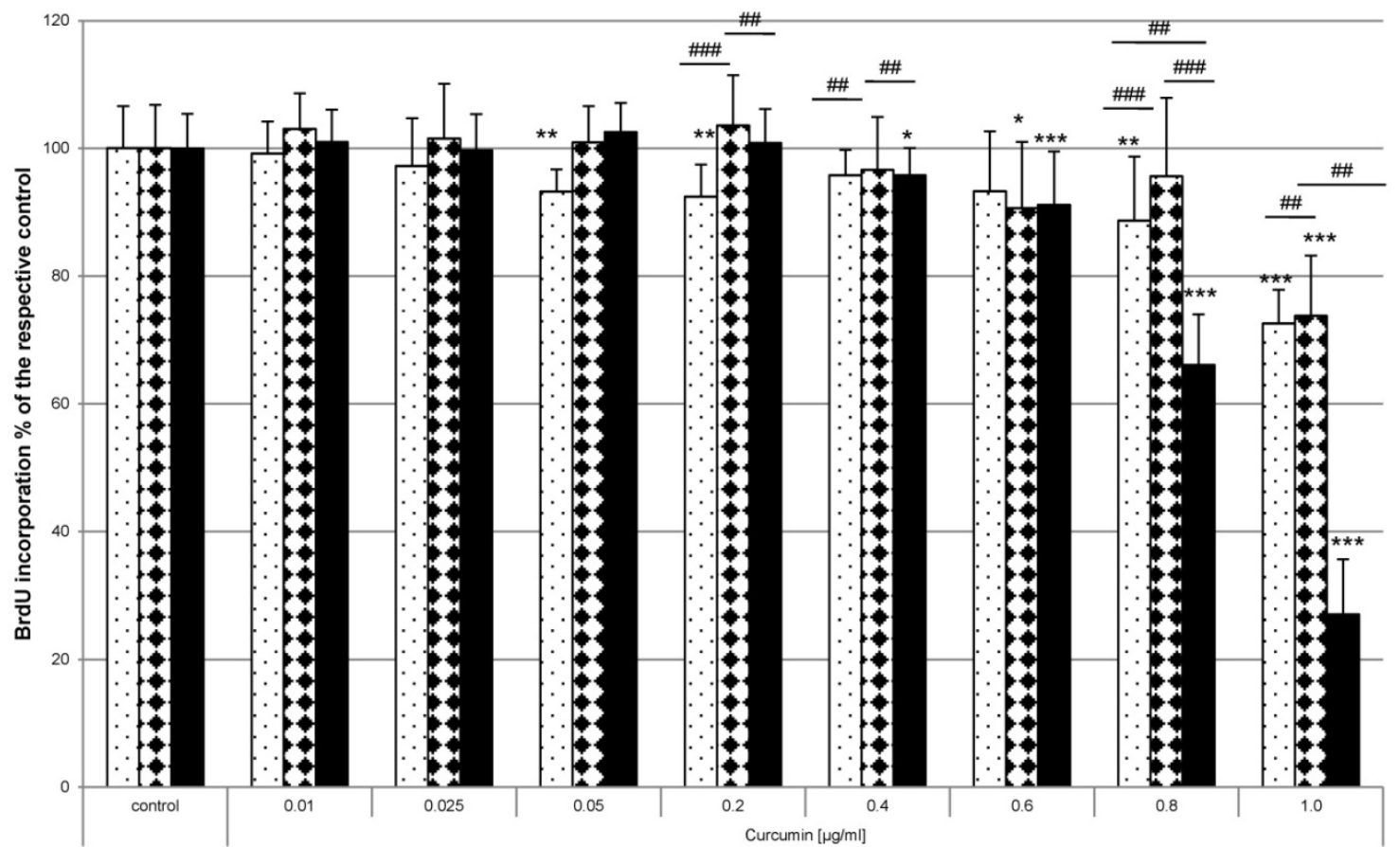

Figure 6. Curcumin in combination with VIS inhibits proliferation in different cell lines. HaCaT (pointed bars), A431 (bricked bars) and HN cells (black bars) were pre-incubated with curcumin and thereafter irradiated with VIS. The proliferative potential was monitored by BrdU incorporation for $16 \mathrm{~h}$ after the treatment. BrdU incorporation was reduced depending on the applied curcumin concentration and investigated cell specie. The data displayed are representative of three experiments performed with comparable results. Average absorbance values (mean \pm SD) from sextuplicate replicates per experimental condition were calculated. $* p \leq 0.05, * * p \leq 0.01, * * * p \leq 0.001$, versus the respective control and $\#=0.01$, \#\# $p \leq 0.001$, versus another cell line treated with the same curcumin concentration.

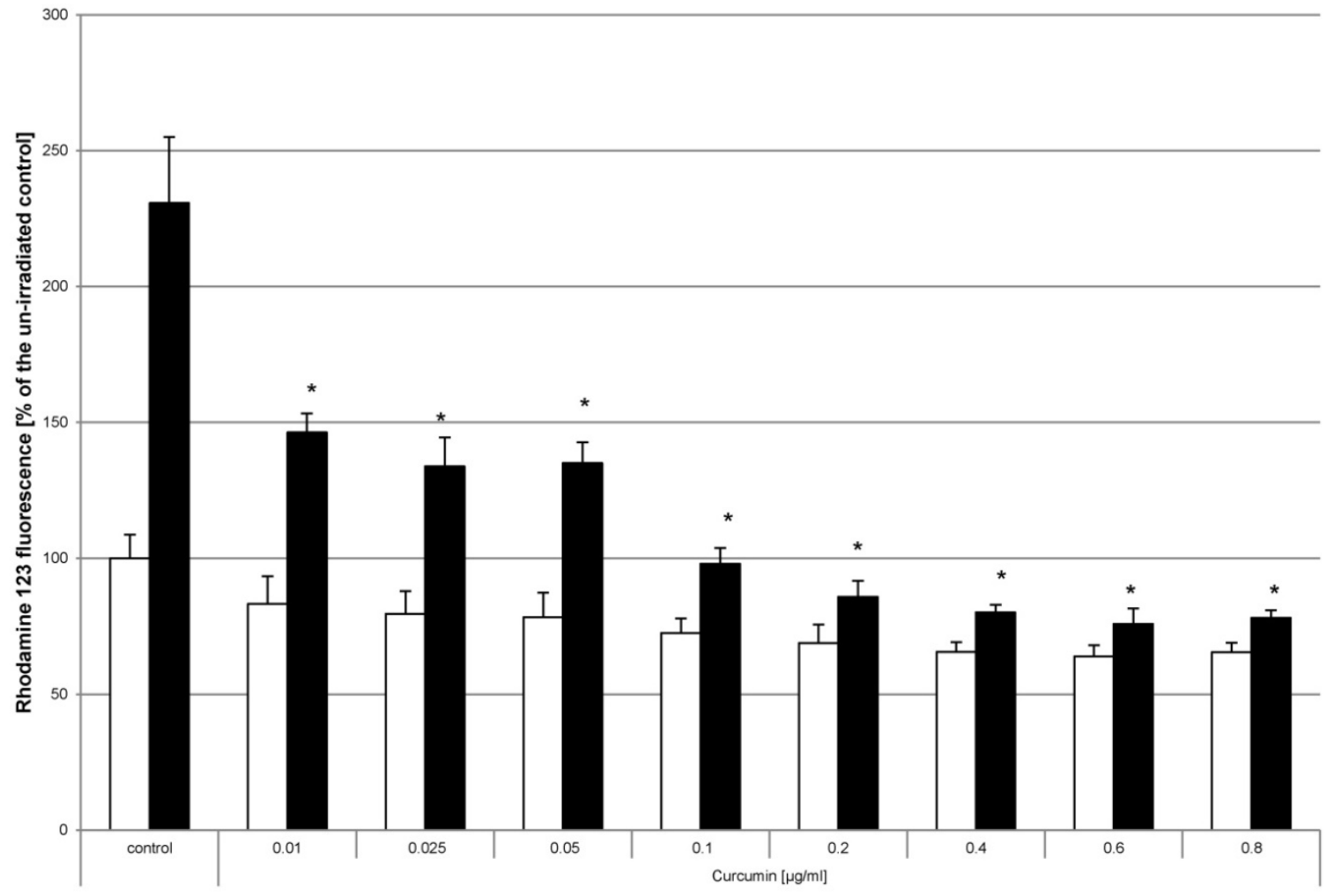

Figure 7. Curcumin reduces VIS related oxidative stress $\mathrm{HN}$ cells were pre-incubated with dihydrorhodamine and curcumin. Thereafter the cultures were irradiated with VIS for $5 \mathrm{~min}$ (black bars) or were kept light protected (white bars). Fluorescence measured after 60 minutes is shown. The values of the un-irradiated controls were set to $100 \%$. The data displayed are representative of three experiments performed with comparable results. Average absorbance values (mean \pm SD) from sextuplicate replicates per experimental condition were calculated. * $\leq 0.05$ versus the irradiated control. 

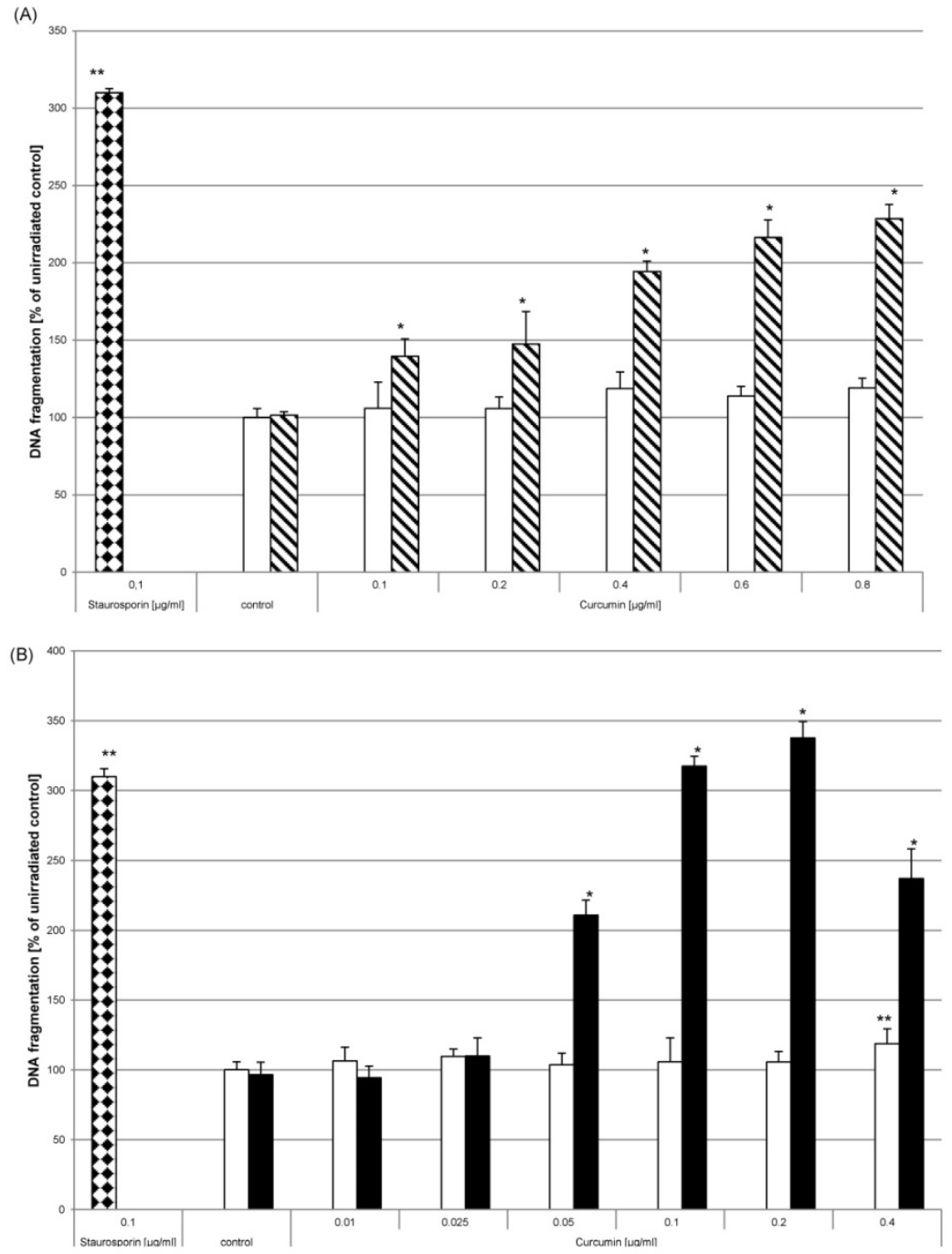

Figure 8. Apoptosis is induced by curcumin-UVA or curcumin-VIS treatment. HN cells were pre-incubated with curcumin and thereafter irradiated with UVA (A) or VIS (B). DNA fragmentation was evaluated after 15h. The applied curcumin concentrations had no effect on DNA fragmentation (white bars). Combining curcumin with UVA (striped bars) or VIS (black bars) induced concentration dependent increase of DNA fragmentation comparable to a treatment with $0.1 \mu g / \mathrm{ml}$ staurosporine (bricked bars). The data displayed are representative of three experiments performed with comparable results. Average absorbance values (mean \pm SD) from sextuplicate replicates per experimental condition were calculated. $* \mathrm{p} \leq 0.05$ versus the respective un-irradiated control.

\section{Curcumin and light induced DNA fragmentation}

Apart from reducing proliferation the induction of apoptosis is also a desired effect to target tumour cells. As analytical parameter for apoptotic processes we monitored DNA fragmentation. HN cells were seeded in multiwell plates. After adherence they were either left untreated, were treated with $0.1 \mu \mathrm{g} / \mathrm{ml}$ staurosporine (bricked bars) or were pre-incubated with curcumin $(0.01 \mu \mathrm{g} / \mathrm{ml}-0.8 \mu \mathrm{g} / \mathrm{ml})$ prior to irradiation. Curcumin alone did not induce DNA fragmentation (Fig. 8, white bars). DNA fragmentation of cell cultures treated with curcumin and light was significantly increased. After UVA irradiation (Fig. 8A, striped bars) an increase of DNA fragmentation in comparison to the irradiated control of $40 \%(0.1 \mu \mathrm{g} / \mathrm{ml}$ curcumin $)$ to $129 \% \quad(0.8 \mu \mathrm{g} / \mathrm{ml}$ curcumin) was observed. Analysing DNA fragmentation of curcumin/VIS treated cultures showed a $110 \%$ increase after pre-incubation with $0.05 \mu \mathrm{g} / \mathrm{ml}$ curcumin. The DNA fragmentation after VIS irradiation (Fig. 8B, black bars) increased depending on the applied curcumin concentration up to a final concentration of $0.2 \mu \mathrm{g} / \mathrm{ml}$ curcumin. Further increasing the curcumin concentration to $0.4 \mu \mathrm{g} / \mathrm{ml}$ resulted in a decreased DNA fragmentation in comparison to the cultures treated with $0.2 \mu \mathrm{g} / \mathrm{ml}$ curcumin. Immunhistochemical staining of cleaved caspase-3 (Fig. 9) showed a concentration dependent increase of cleaved caspase- 3 positive cells $4 \mathrm{~h}$ after treatment with $1 \mu \mathrm{g} / \mathrm{ml}$ (Fig. 9E) and $10 \mu \mathrm{g} / \mathrm{ml}$ camptothecin (Fig. 9F). Furthermore it could be shown that incubation with $1 \mu \mathrm{g} / \mathrm{ml}$ Curcumin (Fig. 9C) alone induced a slight induction of caspase-3 cleavage. Irradiation with VIS (Fig. 9B) induced no 
caspase-3 cleavage. After the combination treatment of curcumin and VIS (Fig. 9D) an increased number of cleaved caspase- 3 positive cells as well as an increase of fluorescence intensity could be observed.

\section{Discussion}

Oral squamous cell carcinomas have a high incidence and recurrence rate [35] as well as a low 5 year survival rate [4, 5]. Amending therapeutic options is therefore highly desired. During the last decades a re-orientation to natural compounds that have been used for centuries in traditional medicine is observed. Among those is the phytochemical curcumin. It is qualified as a cancer therapeutic due to its low risk of adverse events $[36,37]$ in comparison to other cytostatics. Another beneficial factor is that curcumin targets a broad range of signalling pathways [38] that are involved in cancer and inflammatory diseases $[39,40]$. To overcome the obstacle of the low bioavailability of curcumin [14] we have established a photodynamic treatment combining low curcumin concentrations and radiation with either UVA or VIS. Differences of efficiency of the two light entities were observed. The effects induced after VIS treatments were more potent than after UVA treatments. This correlates to the absorption maximum of curcumin at $420 \mathrm{~nm}$ [42]. The spectrum of VIS (380-780nm) overlaps this absorption peak whereas UVA (315-400nm) can only peripherally activate curcumin which has an absorption range of 300 to $500 \mathrm{~nm}$. We previously showed that cell proliferation was reduced and apoptosis induced after photodynamic treatment of cancerous and non-cancerous cell lines $[23,24]$ as well as in a mouse xenograft tumour model [25].
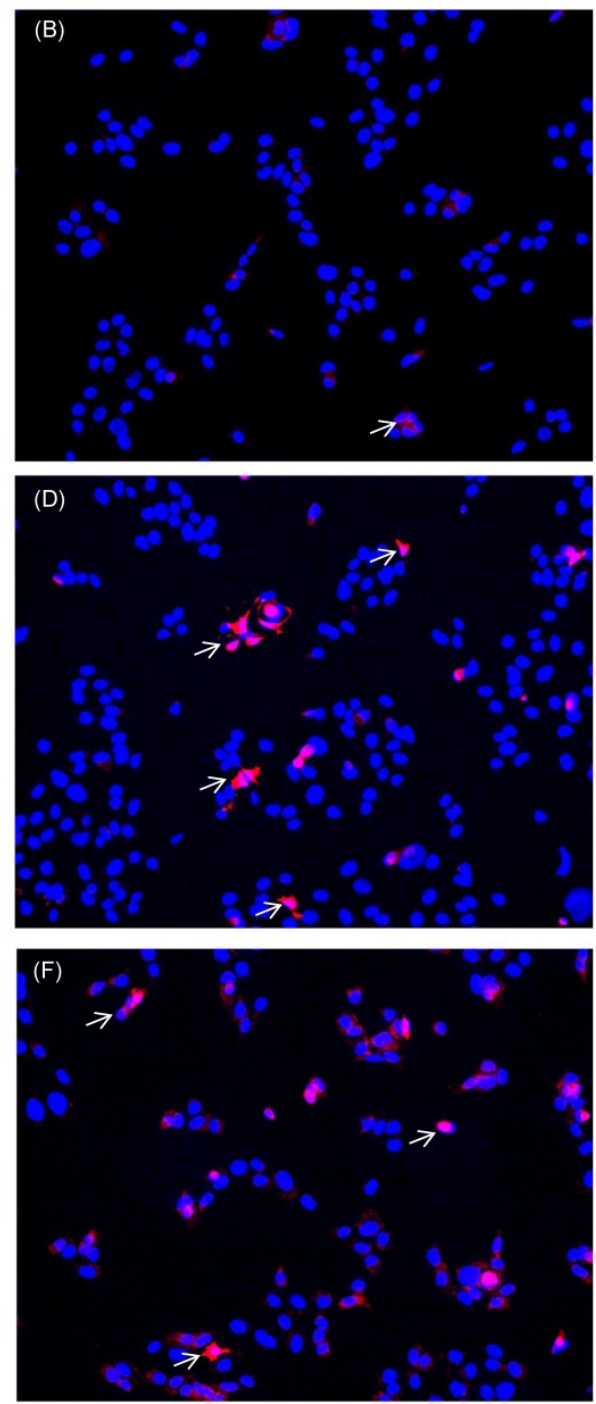

Figure 9. Caspase-3 cleavage is induced by curcumin-VIS treatment and camptothecin. HN cells were either cultivated in control medium (A, B) or were pre-incubated with $1 \mu \mathrm{g} / \mathrm{ml}$ curcumin $(C, D)$. Thereafter they were irradiated with VIS (B, D) or were kept light protected (A, C). As apoptotic inducer camptothecin was used in two concentrations; $1 \mu \mathrm{g} / \mathrm{ml}(\mathrm{E})$ and $10 \mu \mathrm{g} / \mathrm{ml}(\mathrm{F})$. Caspase- 3 cleavage was analysed after $4 \mathrm{~h}$. Cleaved caspase-3 positive cells are indicated by white arrows exemplarily. 
In this study we analysed whether curcumin can also be used for oral squamous cell carcinoma. In this context we particularly focused on tumour-relevant parameters such as proliferation and apoptosis. Of great interest was that $\mathrm{HN}$ cells were more sensitive to the photodynamic treatment than epidermoid carcinoma cells or the keratinocyte cell line HaCaT. Clear cell line specific reduction of the proliferative potential after photodynamic treatment with curcumin was evident. Treating primary gingiva fibroblasts and human submandibular cancer cells using curcumin doses of up to $10 \mu \mathrm{M}$ in combination with or without successive irradiation with a dental lamp [41, 42] revealed a concentration dependent viability reduction. In contrast to our results these effects were first observed after application of concentrations higher than $1 \mu \mathrm{M}$ curcumin. Reduction of cell proliferation was already observed after combination treatment of $0.05 \mu \mathrm{M}$ curcumin and VIS. Even though the enzyme activity of lactate dehydrogenase $24 \mathrm{~h}$ after curcumin-light treatment was increased in comparison to the untreated control, there was still a highly significant difference to the enzyme activity of cultures whose membranes had been lysed with Triton X-100. Lactate dehydrogenase enzyme activity is classically used as indicator for cell membrane damage [34] and therefore indicates necrosis. In absence of phagocytosis it has been described that apoptosis can lead to processes that are called secondary necrosis [43] due to membrane disintegration. It is very likely that the lactate dehydrogenase enzyme activity increase in this study is related to secondary necrosis. The irradiation dependent induction of DNA fragmentation and caspase activation are positive indicators for apoptosis [44-46]. In some cases cytotoxicity and apoptosis are induced by ROS release [32, 41]. The reduced ROS secretion after the photodynamic treatment can be considered as another indicator that cytotoxicity in the used concentrations is not likely and that apoptosis is induced in a ROS independent fashion. Tumour progression is a very complex process. Oxidative stress is one factor that promotes tumour progression [47]. Therefore inducing apoptosis, reducing proliferation and oxidative stress seems a promising therapeutic strategy. Compared to the sole oral application of curcumin the application of curcumin and light irradiation has many advantages in clinical use. The combined treatment of light irradiation and curcumin requires significantly lower concentrations of curcumin to achieve the desired effects [48]. Moreover, the anti-tumorigenic effects are limited to the irradiated area protecting the surrounding tissue. The combined curcumin/ irradiation treatment represents a reasonable addition to the established anti-cancer therapies and can be applied in combination with the approved methods of tumour excision, radiatio and chemotherapy. Nearly all areas in the buccal cavity can be treated with curcumin, e.g. in the form of a cream. Irradiation through an optical fibre is easy to realize with standard equipment. The photodynamic treatment with curcumin and light represents a reasonable addition to the established treatment regimens of oral tumours.

\section{Conclusion}

Curcumin in low concentrations is a potential candidate for photodynamic therapy of oral squamous cell carcinoma due to its anti-proliferative and pro-apoptotic potential. Further studies utilising tissue and animal models will evaluate this innovative treatment.

\section{Abbreviations}

BrdU: 5-bromo-2'-deoxyuridine; DNA: deoxyribonucleic acid; HN: human oral squamous cell carcinoma cell line; LDH: lactate dehydrogenase; ROS: reactive oxygen species; UVA: ultraviolet-A; VIS: visible light

\section{Acknowledgment}

The authors are grateful to Dr. Adrian Sewell for comments and discussion and Stefanie Hoffmann and Monika Doll for technical support.

\section{Competing Interests}

The authors have declared that no competing interest exists.

\section{References}

1. Chen YJ, Chang JT, Liao CT, Wang HM, Yen TC, Chiu CC, et al. Head and neck cancer in the betel quid chewing area: recent advances in molecular carcinogenesis. Cancer Sci. 2008; 99: 1507-14.

2. Cawson RA, Odell EA. Cawson's Essentials Of Oral Pathology And Oral Medicine. Churchill Livingstone, Edinburgh, London, New York, Oxford, Philadelphia, St. Louis, Sydney, Toronto; 2002.

3. Siegel RL, Miller KD, Jemal A. Cancer statistics, 2016. CA Cancer J Clin. 2016; 66: 7-30.

4. Sawair FA, Irwin CR, Gordon DJ, Leonard AG, Stephenson M, Napier SS. Invasive front grading: reliability and usefulness in the management of oral squamous cell carcinoma. J Oral Pathol Med. 2003; 32: 1-9.

5. Sessions DG, Spector GJ, Lenox J, Haughey B, Chao C, Marks J. Analysis of treatment results for oral tongue cancer. Laryngoscope. 2002; 112: 616-25.

6. Bernier J. Current state-of-the-art for concurrent chemoradiation. Semin Radiat Oncol. 2009; 19: 3-10.

7. Bernier J, Domenge C, Ozsahin M, Matuszewska K, Lefebvre JL, Greiner RH, et al. Postoperative irradiation with or without concomitant chemotherapy for locally advanced head and neck cancer. The New England journal of medicine. 2004; 350: 1945-52.

8. Fan KH, Lin CY, Kang CJ, Huang SF, Wang HM, Chen EY, et al. Combined-modality treatment for advanced oral tongue squamous cell carcinoma. Int J Radiat Oncol Biol Phys. 2007; 67: 453-61.

9. Kreppel M, Drebber U, Eich HT, Dreiseidler T, Zoller JE, Muller RP, et al. Combined-modality treatment in advanced oral squamous cell carcinoma: Primary surgery followed by adjuvant concomitant radiochemotherapy. Strahlenther Onkol. 2011; 187: 555-60.

10. Kadioglu O, Cao J, Saeed ME, Greten HJ, Efferth T. Targeting epidermal growth factor receptors and downstream signaling pathways in cancer by phytochemicals. Target Oncol. 2015; 10: 337-53. 
11. Newman DJ, Cragg GM. Natural products as sources of new drugs over the last 25 years. J Nat Prod. 2007; 70: 461-77.

12. Xu YX, Pindolia KR, Janakiraman N, Noth CJ, Chapman RA, Gautam SC. Curcumin, a compound with anti-inflammatory and anti-oxidant properties, down-regulates chemokine expression in bone marrow stromal cells. Exp Hematol. 1997; 25: 413-22.

13. Wang YJ, Pan MH, Cheng AL, Lin LI, Ho YS, Hsieh CY, et al. Stability of curcumin in buffer solutions and characterization of its degradation products. J Pharm Biomed Anal. 1997; 15: 1867-76.

14. Anand P, Kunnumakkara AB, Newman RA, Aggarwal BB. Bioavailability of curcumin: problems and promises. Mol Pharm. 2007; 4: 807-18.

15. Zhang C, Li B, Zhang X, Hazarika P, Aggarwal BB, Duvic M. Curcumin selectively induces apoptosis in cutaneous T-cell lymphoma cell lines and patients' PBMCs: potential role for STAT-3 and NF-kappaB signaling. The Journal of investigative dermatology. 2010; 130: 2110-9.

16. Rashmi R, Kumar S, Karunagaran D. Human colon cancer cells lacking Bax resist curcumin-induced apoptosis and Bax requirement is dispensable with ectopic expression of Smac or downregulation of Bcl-XL. Carcinogenesis. 2005; 26: 713-23.

17. Shoba G, Joy D, Joseph T, Majeed M, Rajendran R, Srinivas PS. Influence of piperine on the pharmacokinetics of curcumin in animals and human volunteers. Planta Med. 1998; 64: 353-6.

18. Singh DV, Godbole MM, Misra K. A plausible explanation for enhanced bioavailability of P-gp substrates in presence of piperine: simulation for next generation of P-gp inhibitors. J Mol Model. 2013; 19: 227-38.

19. Schiborr C, Kocher A, Behnam D, Jandasek J, Toelstede S, Frank J. The oral bioavailability of curcumin from micronized powder and liquid micelles is significantly increased in healthy humans and differs between sexes. Molecular nutrition \& food research. 2014; 58: 516-27.

20. Hegge AB, Bruzell E, Kristensen S, Tonnesen HH. Photoinactivation of Staphylococcus epidermidis biofilms and suspensions by the hydrophobic photosensitizer curcumin--effect of selected nanocarrier: studies on curcumin and curcuminoides XLVII. Eur J Pharm Sci. 2012; 47: 65-74.

21. Wang W, Zhu R, Xie Q, Li A, Xiao Y, Li K, et al. Enhanced bioavailability and efficiency of curcumin for the treatment of asthma by its formulation in solid lipid nanoparticles. International journal of nanomedicine. 2012; 7: 3667-77.

22. Yan H, Teh C, Sreejith S, Zhu L, Kwok A, Fang W, et al. Functional mesoporous silica nanoparticles for photothermal-controlled drug delivery in vivo. Angew Chem Int Ed Engl. 2012; 51: 8373-7.

23. Buss S, Dobra J, Goerg K, Hoffmann S, Kippenberger S, Kaufmann R, et al. Visible light is a better co-inducer of apoptosis for curcumin-treated human melanoma cells than UVA. PloS one. 2013; 8: e79748.

24. Dujic J, Kippenberger S, Hoffmann S, Ramirez-Bosca A, Miquel J, Diaz-Alperi $\mathrm{J}$, et al. Low concentrations of curcumin induce growth arrest and apoptosis in skin keratinocytes only in combination with UVA or visible light. The Journal of investigative dermatology. 2007; 127: 1992-2000.

25. Dujic J, Kippenberger S, Ramirez-Bosca A, Diaz-Alperi J, Bereiter-Hahn J, Kaufmann R, et al. Curcumin in combination with visible light inhibits tumor growth in a xenograft tumor model. International journal of cancer Journal international du cancer. 2009; 124: 1422-8.

26. Boukamp P, Petrussevska RT, Breitkreutz D, Hornung J, Markham A, Fusenig NE. Normal keratinization in a spontaneously immortalized aneuploid human keratinocyte cell line. The Journal of cell biology. 1988; 106: 761-71.

27. Dujic J. Effect of curcumin and light on skin- and tumor cells. JW Goethe University Frankfurt; 2008

28. Zöller N, Valesky E, Hofmann M, Bereiter-Hahn J, Bernd A, Kaufmann R, et al. Impact of Different Spa Waters on Inflammation Parameters in Human Keratinocyte HaCaT Cells. Annals of dermatology. 2015; 27: 709-14.

29. Henderson LM, Chappell JB. Dihydrorhodamine 123: a fluorescent probe for superoxide generation? Eur J Biochem. 1993; 217: 973-80.

30. Royall JA, Ischiropoulos $\mathrm{H}$. Evaluation of $2^{\prime}, 7^{\prime}$-dichlorofluorescin and dihydrorhodamine 123 as fluorescent probes for intracellular $\mathrm{H} 2 \mathrm{O} 2$ in cultured endothelial cells. Arch Biochem Biophys. 1993; 302: 348-55.

31. Schneider CA, Rasband WS, Eliceiri KW. NIH Image to ImageJ: 25 years of image analysis. Nat Methods. 2012; 9: 671-5.

32. Onoue S, Kawamura K, Igarashi N, Zhou Y, Fujikawa M, Yamada H, et al. Reactive oxygen species assay-based risk assessment of drug-induced phototoxicity: classification criteria and application to drug candidates. J Pharm Biomed Anal. 2008; 47: 967-72.

33. Onoue S, Tsuda Y. Analytical studies on the prediction of photosensitive/phototoxic potential of pharmaceutical substances. Pharm Res. 2006; 23: 156-64.

34. Yin JJ, Liu J, Ehrenshaft M, Roberts JE, Fu PP, Mason RP, et al. Phototoxicity of nano titanium dioxides in HaCaT keratinocytes--generation of reactive oxygen species and cell damage. Toxicol Appl Pharmacol. 2012; 263: 81-8.

35. Jemal A, Siegel R, Ward E, Hao Y, Xu J, Thun MJ. Cancer statistics, 2009. CA Cancer J Clin. 2009; 59: 225-49.

36. Chainani-Wu N. Safety and anti-inflammatory activity of curcumin: a component of tumeric (Curcuma longa). J Altern Complement Med. 2003; 9: 161-8.

37. Aggarwal BB, Kumar A, Bharti AC. Anticancer potential of curcumin: preclinical and clinical studies. Anticancer Res. 2003; 23: 363-98.

38. Goel A, Kunnumakkara AB, Aggarwal BB. Curcumin as "Curecumin": from kitchen to clinic. Biochem Pharmacol. 2008; 75: 787-809.
39. Anand P, Sundaram C, Jhurani S, Kunnumakkara AB, Aggarwal BB. Curcumin and cancer: an "old-age" disease with an "age-old" solution. Cancer Lett. 2008; 267: 133-64.

40. Aggarwal BB, Gupta SC, Sung B. Curcumin: an orally bioavailable blocker of TNF and other pro-inflammatory biomarkers. Br J Pharmacol. 2013; 169: 1672-92.

41. Atsumi T, Tonosaki K, Fujisawa S. Induction of early apoptosis and ROS-generation activity in human gingival fibroblasts (HGF) and human submandibular gland carcinoma (HSG) cells treated with curcumin. Arch Oral Biol. 2006; 51: 913-21.

42. Atsumi T, Tonosaki K, Fujisawa S. Comparative cytotoxicity and ROS generation by curcumin and tetrahydrocurcumin following visible-light irradiation or treatment with horseradish peroxidase. Anticancer Res. 2007; 27: 363-71.

43. Krysko DV, Vanden Berghe T, D'Herde K, Vandenabeele P. Apoptosis and necrosis: detection, discrimination and phagocytosis. Methods. 2008; 44: 205-21.

44. Chang PY, Peng SF, Lee CY, Lu CC, Tsai SC, Shieh TM, et al. Curcumin-loaded nanoparticles induce apoptotic cell death through regulation of the function of MDR1 and reactive oxygen species in cisplatin-resistant CAR human oral cancer cells. Int J Oncol. 2013; 43: 1141-50.

45. Zhang L, Man S, Qiu H, Liu Z, Zhang M, Ma L, et al. Curcumin-cyclodextrin complexes enhanced the anti-cancer effects of curcumin. Environ Toxicol Pharmacol. 2016; 48: 31-8

46. Zhu L, Han MB, Gao Y, Wang H, Dai L, Wen Y, et al. Curcumin triggers apoptosis via upregulation of Bax/Bcl-2 ratio and caspase activation in SW872 human adipocytes. Mol Med Rep. 2015; 12: 1151-6.

47. Meierjohann S. Oxidative stress in melanocyte senescence and melanoma transformation. Eur J Cell Biol. 2014; 93: 36-41.

48. Bernd A. Visible light and/or UVA offer a strong amplification of the anti-tumor effect of curcumin. Phytochemistry reviews : proceedings of the Phytochemical Society of Europe. 2014; 13: 183-9. 